\title{
ADVERTISING IN THE LIGHT OF MODERN ENGLISH MASS MEDIA DISCOURSE: LINGUISTIC ASPECT
}

\section{Zirka V. V.}

\section{INTRODUCTION}

The study is a part of a bigger research on the advertising texts, which function in the mass media as a means of forming the readers' positive attitude to the promoted subject. The phenomenon of verbal influence and manipulation is the focus of many sciences of language and psychology at a time. The manipulative and persuasive intentions of the advertiser could be detected in the realization of the communicative function of the language. Many scholars in linguistics, culture experts, psychologists, philosophers and sociologists (N. Arutiunova, J. Austin, R. Blakar, T.A. van Dijk, J. Lakoff, S. Kara-Mursza, G. Leech, S. Ter-Minasova, A. Wierzhbicka) are engaged in the study and classification of manipulative strategies and means of the implementation. The mass media discourse, apparently, is one of the most widespread and the mostly used, broadened and studied in our days since it is realized in mass media, television, communication and advertising genres. Social and political journalism seeks to satisfy both intellectual and aesthetic needs of listeners and readers. It is noted, that scientific language is characterized as the language of ideas and the language of literary works as the language of feelings. Mass media is the language of both ideas and feelings. A journalist or a copywriter can't convey the importance of the ideas, events or thoughts that are necessary in the certain presented material without the use of emotional means of language.

Mass media is vaguely defined as a medium of communication via television, books, radios, newspapers, magazines, and recently the Internet, designed to reach the majority of people. The most important features of the media discourse are informative and influential. And the text belongs to the mass media discourse if communicative aims of this text are both informative and influential.

During each period of its development, the current affairs makes a significant contribution to the evolutionary processes and influences the literary language and, consequently, through it and on the culture as a whole. For the study of cultural concepts, scientists actively attract both the material of fiction and the mass media, because it is here that not only historical moments are reflected, but also a lot of things one can learn about a person or even a whole people, 
analyzing what they discuss and write about. Journalistic style is used to influence people through media. One of the most important function of mass media texts (newspapers, magazines, television, advertising, posters, booklets, etc.) is the function of influencing people's consciousness which takes place due to the wide use of formal and dignified lexis and phraseology, emotionally colored words, the use of short sentences, rhetorical questions, repetitions and other things inherent in the mass media discourse. The mass media discourse is currently studied and examined from different points of view. Followers of the traditional approach are T.A. van Dijk, G. Lebon, Ya. Solganyk, A. Grigoriev, T. Dronyaeva, N. Klushina, M. Kozhyna, E. Sheigal and others state on the understanding that the discourse serves political and ideological, socialeconomic and cultural relations. That is why it has increased its significance in the modern world. It has a distinctive vocabulary that correlates with the basic themes in media. Its language is characterized by a hidden or open rating, which depends on a scale of author's values and publications. A special role is allocated to the author, who is an active participant in public communication and creates an information atmosphere. The author arises, on the one hand, as an individual person, and on the other - as the social person of his epoch. He preserves and relays cultural and historical experience. The scholars are of the same opinion that the modern mass media language aims at creativity, rather than stereotype. Despite the desire for briefness and compression in mass media, the (copy)writers strive to make information to be more expressive. The expressiveness of the discourse is achieved with the help of different functional and semantic-expressive elements.

We are of the opinion, that among the functions inherent in the mass media discourse, as M. Kozhyna highlights it, there are two main and leading functions - the function of influence and the informative function. According to the author's standpoint, the function of influence defines such features of the mass media discourse as its ability to induce people to actions, linguistic expressiveness, and simplicity in the presentation, clarity, advertising and evaluation. At the same time, the ability to induce someone to action is implemented in such linguistic signs, as the nature of the language, generality, expressiveness - in the means of figurativeness and novelty, advertising - in headers and in contact with readers, generalized in the forms of the first and third person - in frequent use of "we" and "our". The information function of mass media is related to such features as documentary, objectivity and factoring, its documented-factual accuracy, restraint, official language, its generality, abstraction as a result of the analyticity and factuality ${ }^{1}$.

\footnotetext{
${ }^{1}$ Кожина М.Н. Речеведение и функциональная стилистика. Москва : Флинта: Наука. 2014.
} 


\section{Communicative and manipulative function of influencing texts}

The numerous examinations of the communicative environment and the theory of mass communication (G. Cook, Culler, K. Jensen, J. Fodor, J. Leech, K. Schroder, T. Vestergaard, J. Williamson, I. Kozhemiakin, Yu. Sorokin, Ye. Tarasov) shows that language is the most important, but not the only means of communication. Verbal signs can carry out their communication functions in interaction with signs of a different nature, as exemplified by advertising in mass media (verbal and iconic signs). It is distinguished as a specific verbal-mental activity.

Advertising, as a form of communication, is associated with a wide variety of linguistic areas that require further study of the linguistic methods of transmitting information, influencing the mass consumer, inspiring and prompting him to the desired action, because this is the main goal of all advertising texts. Studies of language advertising media on various aspects were carried out by both Ukrainian and foreign scientists (J. Austin, J. Cook, A. Crompton, M. Geis, G. Leech, M. Shudson, O. Anopina, K. Kaftanjiev, N. Kokhtev, T. Livshits, M. Tomskaia and others). Broadly speaking, advertisers persuade their audience to adopt attitudes to lifestyle, products and services. It is rare to find advertising that seeks to influence explicitly or directly. Less rare are advertisements in which the link to a product or service is implicit or ambiguous. Ad is one of the most common types of influencing texts, whose pragmatic orientation determines the selection of verbal and non-verbal means and ways of organizing them. Thus, the description of the features of the English-language as well as other languages advertising text in the line of pragmatic linguistics represents the topicality of this study.

No doubt, an advert must not be bore and in its turn manipulation in ads should be appropriate. Then it is perceived as inevitable ad. Manipulation is rather essential for advertising, and enough difficult process, not having a clear methodical tool allowing studying it. To our opinion the concept of manipulation in ads is determined as a specific form of spiritual influence that is expressed in the form of hidden, anonymous dominant carried out by a "non-violent" way. According to Alan C. Harris's article entitled, "Sell! Buy! Semiolinguistic Manipulation in Print Advertising", manipulation of linguistic form means that a small idea or object will undergo some enhancement, change, transformation, mutilation, or mutation that is relatively unexpected on behalf of the reader/viewer ${ }^{2}$. The manipulation usually stands out of the ordinary to grab the attention of potential purchasers, which increases the purchasing consideration of the advertised product/service to the exclusion of all other similar products or services.

\footnotetext{
${ }^{2}$ Harris Alan C. Sell! Buy! Sociolinguistic manipulation in print advertising.
} 
Thus, the important and characteristic feature of manipulation is underlined as following: the hidden, of anonymous character, gradual influence, unnoticed, at complete absence of sender (an author of an advertisement), using major out of human motives: his aspiration to possessing - that is always accompanied with satisfaction.

Our observations indicate, that word-play is one of the most widespread manipulative devices while creation of headings, slogans or plausible adverts itself. As well as all basic artistic devices used in creative advertisement, word-play guards commercial interests of the advertiser and thus includes the word designating significant advertising unit. A play with sense (meaning) represents a verbal charade, having solved which the consumer feels proud for his intellectual level which allowed him to solve this riddle ${ }^{3}$. To show how advertising influences women we take the advert from one of glossy magazines (ELLE) which abounds with plausible, mythological, surrealistic advertising texts.

"Must have of November"

Ice eye cream

(To store in the refrigerator)

Note for eyes: cream Eskimo is on the horizon. To remove swellings and dark circles under eyes and to wake even the sleepiest eyes.

- smoothes, lights, removes puffiness

- for any eyes.

As a rule, the incentive that is calculated on the reaction of the consumer assumed by the sender (and it is always the hidden motivation) is contained in the heading of the advertising text. The heading in this advert is not an exception: "Must have of November. Ice eye cream". The title is a riddle, not trite, not cliché, not ordinary, not boring and, the most important of all, goes to the consumer through his/her heart, but not through head (reason). The heading is always called on to draw attention of audience. In this case the heading-riddle correlates with an advertising object as a barbarism in (the Russian) language: "Must have of November". It provides an addressee - a woman with background information: "cream that surely the real lady OUGHT TO HAVE". Acting as a dominant of sense of the text, the heading defines structure of sense of the whole text, anticipating the selection and language means choice (including manipulative one). By its connotation the heading directs expectations of the consumer, inclines $\mathrm{him} / \mathrm{her}$ on a certain perception. Expansion of sense of the title is put in the first phrase addressed to eyes as if to a woman. And she could not omit the

3 Зирка В.В. Манипулятивные игры в рекламе: лингвистический аспект. Изд. 2-е, испр. и доп. Москва : Книжный дом «ЛИБРОКОМ», 2014. 
"Note to eyes"! The continuation of the phrase is rather unexpected for an addressee, - "cream eskimo is on the horizon"!

Unreality is combined with reality and states as means of the psychological start expression. Words acquire magic value: "cream eskimo ... to remove swellings, dark circles, to wake up even the most sleepy eyes..." In an unreal picture it is objectified that is not subjectified ("ice cream"), it is animated which is inanimated ("note for eyes"). There is an exit over limits of reality ("to wake even the sleepiest eyes"). An expansion of meaning of the key phrase "must have of November" takes place by means of specification, by allocation of its separate components. A basis for an image creation of the "ice cream" that transfers "must have of November" is the feeling of different modalities and of various degrees of intensity. Verbal lexicon serves (to remove swellings, to wake up eyes; smoothes, lights, removes puffiness) to create the image of the cream. The metaphor ("a cream Eskimo is on the horizon") doesn't expand, but narrows the meaning of the phrase "to store in the refrigerator", defining semantics of the phrase "ice cream" concretely.

The ending - "smoothes, lights..." - together with the heading make a composite ring, and corresponds to the thesis, "that the reality has borders, and imagination - is boundless". The text up to the end remains intriguing.

Adverts of plausible character is perceived with interest, they draw attention of an audience with both linguistic and extralinguistic means. However unusual combinations of words ("cream eskimo is on the horizon, to wake up sleepy eyes, smoothes, lights") "hold" the breath of women. The manipulation of a woman happens with the help of attractive - evaluative and verbal lexis, epithets, metaphors, and a barbarism. All these means don't prevent her to decode the text and reveal its implicit meanings; solve the creator's intentions of the advert - to influence.

Film AD Announcement (FAA) is a type of Intellectual Smart Ad and to study its language peculiarities is relevant. It is necessary to note that Intellectual (Smart) Advert (ISA) as a kind of a secondary text is considered here to be the form of short, but high-quality advertising text - a summary to a literary work or must-see film. The term "résumé" dates back to the French resume, meaning "to summarize", "to annotate", "to sum up briefly". A lexical entry of the word resume in the English dictionary is recorded in the following interpretation: "a summary of something is a short account of it, which gives the main points but not the details" (highlighted by V.Z.). Being a brief description of any novel, publication or manuscript, revealing their content (usually in the form of main themes' list), a summary specifies

4 Зирка В.В. Манипулятивные игры в рекламе: лингвистический аспект. Изд. 2-е, испр. и доп. Москва : Книжный дом «ЛИБРОКОМ», 2014. 
their (literary works) purpose, some of the recipient's data, scientific or artistic value. Film AD Announcement as the object of our study is regarded the text of influence on the reader while giving information about some film or cultural event and a social-oriented text. In this regard, we consider the examination of modeling of socially-oriented advertising texts designed to influence the target audience placed in the media to be of great importance.

The pragmatic task facing advertisers (copywriters) is to convey a message whose purpose is to arouse the interest of the reader and have an impact on the customer - to encourage some activities, in our case, to read FAA to the end and buy tickets to watch a particular movie. From the position of linguistic influencing, persuasion and manipulation - the advert is an appeal to the consumer, "dressed" in emotionally-evaluative symbols manipulative components (attractive-evaluative) lexis, borrowings, precedent phenomena, newly created words; grammar peculiarities etc.). These symbols are called on the basis of emerging associations, to give vent to imagination, arouse and impose the necessary images and desires ${ }^{5}$.

Pre-describing the lexical means of FAA, we emphasize that any analysis of verbal means of the influencing text is impossible without taking into account psycholinguistic features. These include the linguistic components of the well-known psychological formula AIDA. The AIDA model is widely known to be used in marketing and advertising to describe the steps or stages that occur from the time when a consumer first becomes aware of a product or brand through to when the consumer trials a product or makes a purchase. The steps proposed by the AIDA model are as follows: Attention the consumer becomes aware of a category, product or brand (usually through advertising); Interest - the consumer becomes interested by learning about brand benefits and how the brand fits with lifestyle ${ }^{6}$; Desire - the consumer develops a favorable disposition towards the brand; Action - the consumer forms a purchase intention, shops around, engages in trial or makes a purchase ${ }^{6}$.

The term, AIDA and the overall approach are commonly attributed to American advertising and sales pioneer E.St. Elmo Lewis. In one of his publications on advertising, Lewis postulated at least three principles to which an advertisement should conform: three qualities of success - on his words. The mission of an advertisement is to attract a reader, so that he will look at the advertisement and start to read it; then to interest him, so that he will continue to read it; then to convince him, so that when he has read it he will believe it. If an advertisement contains these three qualities of success,

5 Зирка В.В. Манипулятивные игры в рекламе: лингвистический аспект. Изд. 2-е, испр. и доп. Москва : Книжный дом «ЛИБРОКОМ», 2014.

${ }^{6}$ URL: C:IProgramData\ABBYY\Lingvo\15.0\Dic \System\CollinsCobuildEnEn.lsd. 
the author underlined, it is a successful advertisement ${ }^{7}$. It was Lewis, who developed his discussion of copy principles on the formula that good copy should attract attention, awaken interest, and create conviction. In fact, the formula with three steps appeared anonymously in the February 9, 1898, issue of Printers' Ink: The mission of an advertisement is to sell goods. To do this, it must attract attention, of course; but attracting attention is only an auxiliary detail. The announcement should contain matter, which will interest and convince after the attention has been attracted. The importance of attracting the attention of the reader as the first step in copywriting was recognized early in the advertising literature as is shown by the Handbook for Advertisers and Guide to Advertising: The first words are always printed in capitals, to catch the eye, and it is important that they should be such as will be likely to arrest the attention of those to whom they are addressed, and induced them to read further.

Having examined the FAAs we should discuss for later stating that: 1) these type of texts belong to the type of prose of the mass media discourse; 2) they are of explanatory character; 3) they cover four basic types of prose: narration, description, exposition and argument; 4) they are the texts of influence; 5) target audience (sex and age) is quite significant; 6) lexis, semantics and grammar of FAA made consumer take right decision while anticipating the film. Anticipation is a feeling of excitement that is distinctive for advertising as a whole, when a customer forestalls something pleasant or exciting that should happen (in his life).

It is common knowledge that advertising is highly derivative and imitative in the genres, text types and structures it uses. In effect, any kind of text that exists for any other purpose may be the blueprint for an advertisement. This is not a one-way relationship: dramatic narratives and comic animations often borrow structures and techniques that first appeared in advertising. FAA is not exclusion and belongs to explanatory writing which can take many forms: a movie review, an explanation of new software, an analysis of historical causes, a report on a recent political development, a biographical sketch etc. It tends to be about information; exploratory writing tends to be about ideas. These are just a few possibilities. The distinguishing feature of all these examples and other kinds of explanatory writing is that the writer either knows most of what he or she is going to say before starting to write or knows where to find the material needed to get started. A typical explanatory essay might be on some aspect of global warming or COVID virus (for instance). The material for such a paper already exists - nobody's going to create it or discover it within his subconscious. His or her job as a writer is to dig out the material, organize it,

\footnotetext{
${ }^{7}$ Knox Lewis W. Builder of Business. The Caxton, No. 11(4), January 1911, p. 14.
} 
and shape it into a clearly written, carefully supported essay. Usually a copywriter of movie review knows who his readers are (for an explanatory essay) and, from the beginning, shape it for that audience.

Copywriters or just writers usually make plans when they are doing explanatory writing, plans that can range from a page of notes to a full outline. Such plans help them to keep track of their material, put it in some kind of order, and find a pattern for presenting it. For explanatory writing, many copywriters find that the traditional methods work well; assertion or support, cause and effect, process, compare or contrast, and so on. Many magazine articles and notification books are primarily explanatory writing. It's a crucially important kind of writing, one that we depend on for information and education. Explanatory writing is not necessarily easy to do nor is it usually formulaic. It takes skills and care to write an accurate, interesting story about or an entertaining and informative report on how the film (movie) was made. But the process for explanatory writing is manageable. The task should be identified, the purpose should be decided and who the audience is should be settled (to use adequate lexis), a plan for finding and organizing information should be mapped out. All these features are fully represented in an FAA.

A very common general approach of FAA is to create narratives - which may be self-contained or episodic with a plot consisting of three or four statements. FAA is studied here as a traditional type of prose. In its turn, prose is regarded as the ordinary language people use in speaking or writing. It's a form of language that has no formal metrical structure. It applies a natural flow of speech, and (sometimes) ordinary grammatical structure. Usually four basic types are referred to prose (they are important for us): narration, description, exposition and argument $^{8}$. All these types are evidently reflected in Film $\mathrm{AD}$ Announcement. Thus, to narrate is to tell a story, to tell what happened or is going to be happened. While narration is most often used in fiction, it is also important in nonfiction, either by itself or in conjunction with other types of prose. A good narrative essay has four essential features. The first is context: the copywriter makes clear when the action happened, where it happened, and to whom. The second is point of view: the copywriter establishes and maintains a looking on. The third is selection of detail: the copywriter carefully chooses what to include, focusing on those actions and details that are most important to the story while merely mentioning or actually eliminating others. The fourth is organization: the copywriter organizes the event of the narrative into an appropriate sequence. It is often a strict chronology with a clear beginning, middle, and end.

\section{P. 504.}

${ }^{8}$ Language Awareness. University of Vermont. St. Martin's Press. New York. 1994. 
As a basic type of prose argument is very significant for the influencing texts as ads are. Therefore, to argue is to attempt to convince a reader agree with a point of view, make a given decision, or pursue a particular course of action. Logical argument is based upon reasonable explanations and appeals to the reader's intellect.

Description in FAA is a plot. It tells how a person, place, or thing is perceived by the senses. Objective description reports these sensory qualities factually, whereas subjective description gives the copywriter's interpretation of them.

The purpose of exposition is to show the result, clarify if needed, explain, inform and encourage to action. The methods of exposition are process analysis, definition, division and classification, comparison and contrast, and cause and effect analysis.

All these types of prose become apparent in the Britain newspapers' announcements, and confirm that AAFs are the adverts of manipulative (influencing and persuasive) type. Advertising often makes use of short texts - whether in print or broadcast media - where every word has to work "hard". It is very common for copywriters to use words that belong to some other special lexicon, as if to establish a rapport with the target audience. It is common knowledge that the advertising text specifically reflects the society to which a particular advertising is addressed.

Not the least of the factors for persuasive texts to be examined in media is distinctive structures. First, we should identify what such persuasive media texts might be. Some are easy to name, as they are explicitly intended to alter our view. What are the structures for these texts? They may be a few hundred words in length - a headline, a simple introduction, an elaboration of argument with examples, leading to a simple conclusion or extended advertisements. While the lexicon and style may vary according to the target audience of the newspaper, the structure is more or less the same for different kinds of newspaper.

Among the language units used by advertisers to characterize the promoted object, adjectives and adverbs undoubtedly prevail. It is these categories of words that are correlated in language with attractive lexis and are characterized by a huge variety of evaluative semantics. "The language of evaluations is extremely adapted for the use in a decision-making situation, instructions on the choice or changing of the principles of choice and modification of standards," this is how advertising researchers explain the introduction of evaluative predicates in the field of informing, attracting attention and motivation for action ${ }^{9}$. Since the evaluation predicates

\footnotetext{
9 Арутюнова Н.Д. Истоки, проблемы и категории прагматики. / Н.Д. Арутюнова, Е.В. Падучева. Новое в зарубежной лингвистике. Москва : Прогресс, 1985. С. 14.
} 
convince the consumer and confirm the idea of superiority (or advantage) of goods over the goods-competitors, so they form the influencing component of the advertising text. Being an active component of the advertising text, evaluative lexis, therefore, is an integral part of the manipulative strategy of the advertising discourse. The frequency of evaluative lexis functioning in adverts also deserves special attention. Our interest in evaluative lexis is caused by the fact that some part of this "emotional" lexis is somewhat like a stable professional lexicon, without which no copywriter can do along. Evaluations in advertising often replace logical reasoning; thus, evaluative assertions often take on the character of arguments. The peculiarity of evaluative lexis use in the advertising text leaves its mark on the very system of evaluative lexis, on the semantics of evaluative structures.

Hierarchies of values and emotions are an important component of the world picture; they determine the system of representations of man. The use of value categories, value argumentations are significant in the language of advertising. In fact, at present, such an advertising text is rarely found in which the incitement to action - i.e. to the instant purchase of goods - would not be expressed using evaluative vocabulary. Therefore, we can confidently state that the main sign of advertising announcement is the frequency of rating predicates. As a result of this, the specificity of advertising lies in the fact that it is the evaluation category that is reflected in the advertising text.

Advertising on the whole (including FAA) has a lexicon, which may change over time, but is fairly stable - new, improved, proven and other qualifiers are seen as reliable. David Ogilvy in Confessions of an Advertising Man (quoted by Shirley Russell) identifies a basic lexicon of qualifiers such as: new, good, crisp, better, fresh, natural, fine, free, and of verbs such as: buy, give, taste, go, look, feel and use. Special registers (technical, scientific or pseudo-scientific) may be used for appropriate products.

Lexical choices, as we can see later, reflect shifts in subjective meaning or connotation or contemporary attitudes, so that they (choices) carry a sense of approval or disapproval in making a decision. They may also be euphemistic, appearing as an acceptable substitute for some word or phrase that the copywriter thinks to be too strong or direct. We can state, that the leading place in the FAAs belongs to emotive and evaluative lexis when describing the modern world value picture or while reflecting the priority of cultural values. The valuable properties for the consumer of today (as, indeed, it was and the 20th or 19th centuries) are still novelty, cheapness, modernity, uniqueness. This is confirmed by the ads, the advertising effect of which is achieved by the often repeated predicates like effective, new, the latest, the newest, the recent, modern, innovative, frontier, cutting-edge, state-of-the-art, cheap, unique, exclusive, reasonable/moderatelaffordable and the like. 


\section{Pragma-linguistic analysis of film ad announcement}

To arouse interest an advert should contain good word choice. Emotions proved to be part of advertising discourse, being one and the main factors in regulating consumer's behavior as well as shaping decision-making. The means of emotional expressiveness - attractive and evaluative lexis - with the aim of manipulating the audience decision is noticeable in the modern mass media and become a focus of interest of many scholars. Successful advertisements always appeal to emotions rather than rationality. Thus none of FAA and commercials can do without attractive-evaluative predicates they make us happy. One could even conclude that attractive and emotional words attract target audience. The more - the better. Verbal play and creativity are two modern tends in promoting new expressions, new meaning and making up successful advert. Because the purpose of it is to influence, manipulate, persuade.

It is relatively easy to study grammar in FAA, by looking at very specific features of language data such as verb tenses and pronoun choices - these can become conventional in certain forms or genres, and harden into a kind of style. Firstly, advertising often allows the author more permission to depart from standard forms than in other kinds of text. And secondly, it makes use of short forms or short sentences. Copywriters use imperatives ("Look at the clues"), make statements ("We don't serve coffee in the directors' dining room") or plant noun or noun-phrases ("whodunit", "We'll double your many back"; "Free servicing for 3 years") and leave us to work out what to do about our decision. There is a connection with pragmatics, therefore, in that the copywriter makes very great assumptions about the target audience. It is acceptable to cause readers to feel confused because they cannot understand something - puzzle them - or intrigue in ways that would not be at all appropriate if the audience really depended on the copywriter's information.

One very common technique in the studied texts is for the author to set nouns and noun phrases or verbs on their own, where the reader supplies the missing elements by conjecture - rather as in interpreting notes. This form may sometimes but not always resemble the forms used in headlines, so that it is especially suitable for adverts in newspapers. Here are some examples taken more or less at random through some daily newspapers in Britain (December 2019). We consider the extracted examples of FAAs as adverts of influencing type.

Advertisement Feature.

EXAMPLE No.1. The Lighthouse.

"Following his acclaimed debut The Witch, Robert Eggers returns with this highly anticipated psychological thriller that charts the slow descent 
into madness of two lighthouse keepers on a remote New England island at the turn of the 19th century...

(The format of a story with a plot consists of three or four statements. Narration, description, exposition and argument are given).

...The starkly beautiful black and white images - shot by cinematographer Jarin Blaschke - and the superb sound design, create a hypnotic and hallucinatory fusion of beauty and brutality that combine powerfully with the extraordinary performances from Dafoe and Pattinson's feuding duo".

1) The FAA appeals to a wide audience.

2) Influencing and Persuasion: a hypnotic and hallucinatory fusion of beauty and brutality, psychological.

3) Attractives: superb, hypnotic, highly anticipated; starkly beautiful.

EXAMPLE No. 2. Ordinary Love.

"Actors Liam Neeson and Lesley Manville play a long-married couple coping with a cancer diagnoses in this subtle, emphatic character study written by playwright Owen McCafferty...

(The format of story with a plot consists of three statements.

Narration, description, exposition and argument are given).

...Viewers used to watching Leeson in an action-film context should take pleasure in watching him in a more thoughtful, dramatic role; his relationship with Lesley Manville's character feels intimate, lived-in and warm. She, meanwhile, is the film's true beating heart, giving a sensitive nuanced performance that gives the lie to the idea that there is any such things as an ordinary love".

1) It is a written account of connected events.

2) The "story" is adapted as a romantic novel, entitled "Ordinary Love".

3) Influencing: intimate, lived-in and warm; a sensitive nuanced performance.

4) Attractives: thoughtful, dramatic.

EXAMPLE No. 3. Portrait of a Lady on Fire.

"Romance, erotism and art collide in this sumptuous masterpiece from Celine Sciamma, the first female-directed film to win the Queer Palm at Cannes, where it also won the Best Screenplay award...

(The format of story with a plot consists of four statements.

Narration, description, exposition and argument are apparent).

...Renowned for gritty, social-realist coming-of-age tales like Girlhood (CINECITY 2014) and Water Lilies (CINECITY 2007), the film marks a distinctive turn for Sciamma. Portrait of a Lady on Fire moves her focus away from contemporary concerns and back in time to a more lush, sensuous style of film-making. What remains is a fiercely feminist commitment to exploring women's stories, a masterful command of image and sound, and a unique cinematic vision. 
1) This more resembles a newspaper editorial.

2) Like editorial, the FAA has a common theme, has a reasonably clear argument, using examples to illustrate it.

3) The copywriter relies on the target audience to supply the connections, so that we do not have an obvious sense of someone's telling us what to think.

4) Attractives and therefore influencing: Romance, erotism and art collide, masterful, sensuous, contemporary, sumptuous masterpiece.

The FAA is perceived with interest, it draws attention of female audience with both linguistic and extralinguistic means: with or without extra graphic decorative detail or feature added to advert to make it more attractive. However unusual combinations of words ("romance, erotism and art collide in this sumptuous masterpiece; fiercely feminist commitment; a masterful command of image and sound") "hold" the breath of women. The manipulation of a woman happens with the help of emotive and evaluative lexis, epithets, metaphors. All these means help woman to decode the text and reveal its implicit meanings, and solve the creator's intentions to watch the movie.

EXAMPLE No. 4. A Cutting Edge Modern Whodunnit.

"Knives Out - a modern murder mystery homage to classic Agatha Christie that audiences are going wild for-has an all-star cast and a plot to keep you guessing to the very end.

From Agatha Christie to Murder, She Wrote, audiences have always loved a good whodunit. The eccentric sleuth. The fiendish crime. The muddled motives and the multiple suspects. Top bombing. It's a beloved genre, designed to keep you guessing until the very last minute...

(The format of story with a plot consists of four statements.

Narration, description, exposition and argument are also given).

...The sensational new film from Rian Johnson, the acclaimed writerdirector behind Looper and Star Wars.

A contemporary classic in the making and the must-see film of the moment from the director of the brilliant Looper, Knives Out will appeal to whodunit fans of all ages...

In cinema Wednesday..."

1) Target Audience - fans of all ages. In this way the advertisement appeals to potential readers of both sexes.

2) Emotive and evaluative predicates in the above FAAs (brilliant, beloved, wild) are targeted at anticipating intrigue that keeps you guessing to the very end: the eccentric sleuth; the fiendish crime; the muddled motives; the multiple suspect etc.

3) Persuasive effect. The copywriter uses the phrase "top bombing". The non-standard noun, bombing, suggests something which is typically male, 
fun and demotic - it is unpretentious, aimed at people who have traditional ideas of bitter as a down-to-earth and blokeish drink - stereotypically male behavior and interests.

4) Naming as a special type of linguistic activity in media is characterized by increased linguistic creativity. The role of naming in the AAF - inventing and selecting "special" words aimed at creating memorable, sonorous and accurate words to characterize both the work as a whole, and individual characters or objects capable of promoting the intellectual product on the market - deserves special attention. Thus, the lexeme "whodunit" in literal meaning "who done it" attracts attention and excites curiosity and interest.

5) Grammar - reduced sentences: The eccentric sleuth. The fiendish crime.

6) Anticipation of intrigue.

The same intriguing factor is seen in the $1^{\text {st }}, 2 \mathrm{~d}$, and $3 \mathrm{~d}$ film adverts - but there the lexis is more explicitly making the distinction. The advertiser wants to suggest that each FAA has a combination of style, flair, power and even youth appeal. Rather than use any of these words, the copywriter has invented its own compound abstract noun - "Whodunnit" that really affects us.

\section{CONCLUSIONS}

In the description of verbal manipulation of the advertising it is important not only to study the language in its pragmatic functions (as a means of exposure, interactions - traditional aspect). It is significant to study verbal human behavior, modeling social and individual behavior through speech, as well as the representation of linguistic information of advertising in total, as control information (pragmatic properties of various language entities of language units of different levels and patterns of their functioning in speech in different communicative situations).

To summarize, we would like to mention that in film advert announcements generally, one should consider the relationship between the copywriter/author and the audience. The essence of linguistic influence and manipulation being an integral part for current ads is being developed by linguists round the world. Influence takes place by the way of voluntary and purposeful use of language system characteristics.

It should be noted that the significance of any advert aimed at the target audience is determined by its ability to attract reader/buyer's attention to the promoted film or published book, revealing its main content, hold interest, create the desire to know where is the intrigue of the movie or novel, assist to the development of solution for buying a ticket on must-see film (or at least reading the film ad announcement to the end). 
Compositional features of a FAA are supplemented, as it was already mentioned above, by particular lexical content - that is by narration, description, exposition and argument. This mode reflects the close relationship of the two main functions of advertising messages: information and influence/persuasion.

As well as commercial, FAA presents the information to a prospective reader selectively. The difference is mostly in target audience (sex and age), and consequently freedom of speech, diversity of attractive and evaluation predicates and newly created lexis. Mass linguistic creativity is the modern tendency in the communicative aspect. Therefore, the task of any copywriter is to find maximum ways of influence on a consumer with minimal but daring and provocative lexical units. This is a fundamental factor for creation of successful advert and indeed and, undoubtedly a Film Advert Announcement is referred to as a means of the mass media.

\section{SUMMARY}

The paper focuses on the problems of modern linguistics in correlation with language, culture and psychology. The mass media discourse as the language picture of the world is studied. The discussion subject of the article concerns the Film Ad Announcement in mass media. It performs nominative, communicative, informative, aesthetic functions, attracts audience and serves as advertisement. The article provides the data of the adverts' linguistic peculiarities. Place and role of stable ad's lexicon are considered. It is characterized by structuralgrammatical, lexical-semantic, linguistic-pragmatic peculiarities. Composition features of the film announcements are shown on the examples. The content, copywriter's intention and conception, intrigue of the plot, attractiveness for the target audience are basic factors for the film advert's creation. Special attention is given to the manipulative/ influencing character of the ads. The AIDA model in this respect is applied. The aim of the Film Ad Announcements in readers' attracting attention, arousing their interest, provoking/exciting their curiosity and desire is proved.

1. Andrew Moore. Language and Power. 2003. URL: http://www.zigzageducation.co.uk (Last accessed: March 2015).

2. Арутюнова Н.Д. Истоки, проблемы и категории прагматики / Н.Д. Арутюнова, Е.В. Падучева. Новое в зарубежной лингвистике. Москва : Прогресс, 1985, 14.

3. Arutyunova N.D. Aksiologiya $\mathrm{v}$ mehanizmah zhizni i yazyka. In Problemy strukturnoj lingvistiki. Moscow : Nauka, 1988. Pp. 5-23.

4. Зирка В.В. Манипулятивные игры в рекламе: лингвистический аспект. Изд. 2-е, испр. и доп. Москва : Книжный дом «ЛИБРОКОМ», 2014. 
5. Harris Alan C. Sell! Buy! Sociolinguistic manipulation in print advertising. URL: http://www.csun.edu/vcspc005/advertis.html.

6. Jerry W. Thomas. Advertising Effectiveness. Decision Analyst. USA. 2007. Arlington. Pp. 1-4.

7. Kannan R., Tyagi S. Use of language in advertisements. English for Specific Purposes, Issue 37, vol. 13, 2013.

8. Karlsson Linda. Advertising Theories and Models. University of Halmstad, Faculty of Economics and Technology, Strategic Marketing. Halmstad, 2007.

9. J.W. Knox Lewis - Builder of Business. The Caxton, No. 11(4), January 1911.

10. Kenneth Roman, Jane Maas. How to Advertise. Building Brands and Business in the New Marketing World. 2003. UK. Chapter 15. 218 p.

11. Кожина М.Н. Речеведение и функциональная стилистика. Москва : Флинта: Наука. 2014.

12. Lewis E. St. Elmo. URL: http://en.wikipedia.org/wiki/aida (marketing)\#cite_note-23.

13. Language Awareness. / P. Escholz, A. Rosa, V. Clark. St. Martin's Press. New York, 1994.

14. Shirley Russell. Grammar, Structure and Style. Oxford. 1994. P. 177.

15. URL: $\quad$ C:IProgramData\ABBYYLLingvol15.0\DiclSystemlCollins CobuildEnEn.lsd.

Information about the author: Zirka V. V.,

Doctor of Philological Sciences, Full Professor Research and Educational Center of Foreign Languages

Dnipropetrovsk Department National Academy of Sciences of Ukraine 15-B, Kn. V. Velykogo str., 81, Dnipro, 49000, Ukraine 